\title{
EDITORIAL: THE USELESS PRECAUTION
}

Opera, at once the grandest and most pretentious of art forms, is one of the hardest to keep alive. Monteverdi, the first great opera composer, wrote (or at least began) upwards of a dozen operas, only three of which have come down to us, complete. Alessandro Scarlatti, who wrote more than sixty operas in the decades either side of 1700 , is represented today only by a handful, many of his manuscripts having not survived. Hardly any opera scores were published before the nineteenth century, the demand for them among the buying public being less than overwhelming.

Yet, clearly, opera refuses to die. Far from being the zombie among art forms, it would be not unreasonable to propose that as many new operas play on the world's stages now as in they did in the midnineteenth century. Opera may be 'The Art of Dying', to quote the subtitle of a recent book by Linda Hutcheon and Michael Hutcheon, but it is not yet a dying art. TEMPO 268 celebrates its robust health in the form of articles on two brilliant modern operas, as different from each other as chalk and cheese.

Much ink has been spilled, and probably a good deal of beer as well, arguing the case for the greatest operas of the late twentieth century ('late' in this case meaning post-Death in Venice). The operas discussed in these pages are clear contenders. The young British composer and scholar Laurence Osborn gives us an insight into the semiotics of sound, meaning and drama in Helmut Lachenmann's Das Mädchen mit den Schwefelhölzern (1990-96), an eerie remake of a mid-nineteenth-century fairy tale by Hans Christian Andersen, instantly acclaimed as a modern masterpiece following its premiere production in Hamburg in 1997. Lachenmann's opera, which already has two complete CD recordings, is unlikely to suffer the fate of Monteverdi's Proserpina rapita or Le Nozze d'Enea con Lavinia; but more complex issues seemed to face the survival in performance of Robert Ashley's opera Perfect Lives (1979-80), originally conceived for television and first screened in its original form on the UK's Channel 4 in its halcyon days in the mid-1980s. While the work is amply documented, on DVD and in the form of a published book, the centrality of Ashley himself as a performer, and the lack of a complete, fully notated score, seemed to militate against the possibility of future performances of the work by others. Not so: in 2011 the New York-based durational experimental performance collective Varispeed stunningly recreated Ashley's opera as a site-specific event, each scene being played in a location matching that of its title ('The Supermarket', 'The Church', 'The Park', 'The Backyard', etc). Varispeed founder member Gelsey Bell writes here of the process of recreating this experimental classic. This raises the fascinating topic of how to bring back to performative life experimental works for which no definitive score exists, a theme that will be explored further in subsequent issues of TEMPO. (For those curious for more information on 
Ashley's work, our Reviews section discusses an excellent new book on him by Kyle Gann.)

A very different, non-operatic form of the relationship of music and text is found in the magnificent fifth string quartet by Horatiu Radulescu, and I am proud to publish the first piece of extended analytical writing on it in the form of an article by the young American composer William Dougherty. The quartet is inspired by, and indeed sonifies, lines from the Tao Te Ching by Lao Tzu, and Dougherty introduces us to the new playing techniques and notational symbols developed by Radulescu in order convey his vision of this ancient text. Still in analytical mode, the US musicologist Alexander Sanchez-Behar describes the use of visual models derived from various kinds of symmetry (reflection, translation and rotation) in the early music of John Adams, and the transformations of these techniques in the composer's more recent work.

The ongoing dialogue between improvisation and composition, addressed in TEMPO 267, is one of the themes in the article by Richard Barrett, originally the keynote address at a conference on notation held at Goldsmiths, University of London last autumn. Barrett's title, 'Notation as Liberation', provocatively inverts the old adage that it is improvisation that liberates musicians from the tyranny of notation. The article offers a nuanced view of the emerging forms of music that exist somewhere between the determinate and the indeterminate, an area of praxis in which Barrett's work exerts an everwider influence.

In an article published in The Musical Times some ten years ago I wrote that the composer Frank Denyer was 'one of the better-kept secrets of English music'. Gratifyingly that comment has become less true with the passage of time, although I suspect many readers of this journal may still not have much of an overall grasp of his complex and inspiring oeuvre. In a contribution to On My Mind, Denyer gives a concise and perhaps shocking vision of the musical landscape in which that work has developed. And our Reviews section profiles the distinguished American composer Christian Wolff, celebrating his eightieth birthday this year, of whose music Denyer (as pianist) has long been a champion.

In these pages we also welcome writing by several reviewers new to the journal, bringing fresh perspectives to their various subjects. TEMPO is firmly committed to publishing work by debutante writers (of all sexes), believing equally in the eructations of youth and the experienced seasonings of the mature. The title of this Editorial in fact slyly alludes to this: The Useless Precaution, as the discerning TEMPO reader will know, is the name of the fictional 'popular opera' mentioned in Rossini's The Barber of Seville (as well as being the subtitle of the opera itself). When in Act 2 Rosina, in the course of a singing lesson, tries out a 'rondo' from this modern opera, her guardian Dr Bartolo complains: 'But this aria, my goodness, is very boring. The music in my day was really something else'. While those of us over 50 may give vent to the occasional Bartolo-style grumblings, there is no doubt that the commitment to the modern by our present-day Rosinas is ultimately far more interesting.

It is with great sadness that the Editors note the passing of Robert Ashley (1930-2014) as this issue was in press. 


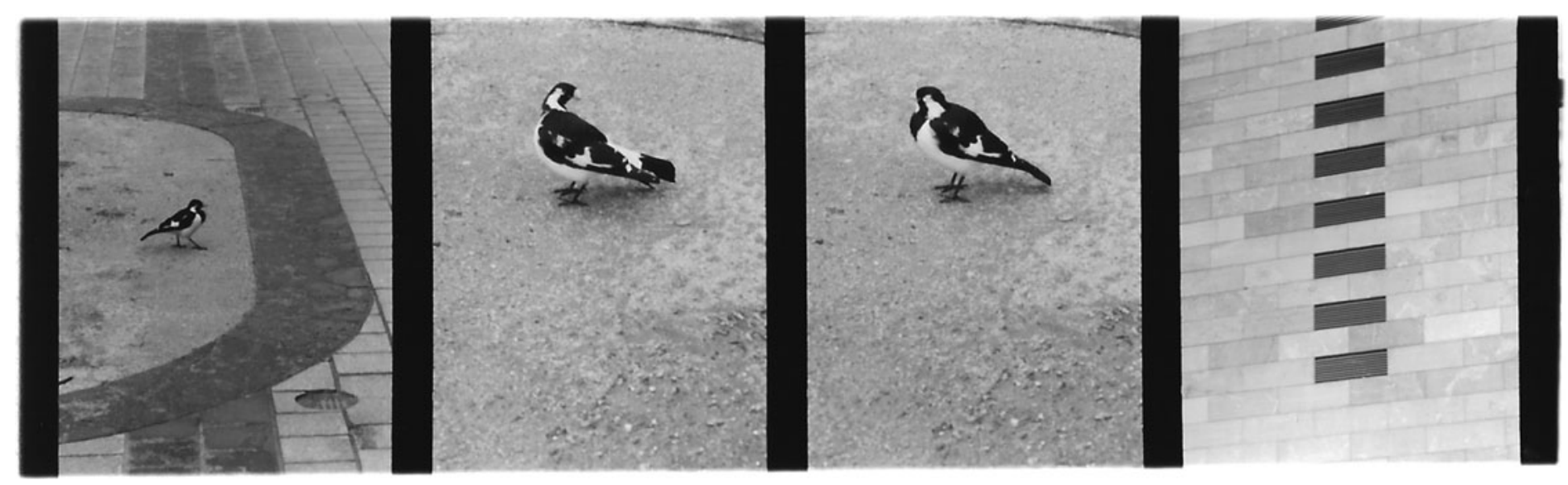

(C) 2013 Anton Lukoszevieze, Quartet Six, silver gelatin print 